\title{
Studies on Foliar Application of Growth Regulators and Macro Nutrients on Seedling Growth of Aonla
}

\author{
M.R. Chiranjeevi, M.K. Sneha, Shivanand Hongal and B.M. Muralidhara* \\ Department of Fruit Science, Post Graduate Centre, GKVK Campus, Bangalore-560 065, \\ Karnataka, India \\ *Corresponding author
}

\section{A B S T R A C T}

Keywords

Aonla, $\mathrm{GA}_{3}$, Seedling height, Fresh weight, Dry weight

Article Info

Accepted:

28 January 2018

Available Online:

10 February 2018
An experiment was conducted at the Regional Horticultural Research and Extension Centre, Bengaluru. The effect of foliar application of different growth regulators and macronutrients on the growth of aonla seedlings was studied. The treatment with $\mathrm{GA}_{3} 300 \mathrm{ppm}$ recorded the maximum seedling height $(37.00 \mathrm{~cm})$, stem diameter $(0.61 \mathrm{~cm})$, number of leaves $(42.33)$, fresh weight $(41.83 \mathrm{~g})$ and dry weight $(3.16 \mathrm{~g})$, while minimum was noticed in control. Correlation matrix was worked out for different characters to known the relationship between the characters. The highly positive relationship among all the traits was obtained except number of days taken to attain graftable stage, which was negatively correlated with all the traits.

\section{Introduction}

Aonla belongs to the family Euphorbiaceae and is native to tropical regions of South East Asia, particularly central and southern India (Mortan, 1990). Aonla is a good source of nutrients and medicine as well and its cultivation is also highly remunerative for small and marginal farmers. Traditionally, aonla has been a wanton crop of forest or household, but during the last decade, unprecedented expansion has been witnessed in the sphere of aonla cultivation across the country, utilizing the wasteland. Considering the high productivity per unit area, hardy nature, medicinal value and number of uses, there is every possibility that aonla will be one of the most important fruit in near future. In the recent years, considering its prospects particularly in the wasteland situation, area under aonla cultivation is increasing rapidly.

The seedling growth of aonla is very slow and takes more time to attain graftable/buddable stage. Aonla being a minor fruit crop, less work has been taken for enhancing the seedling growth by foliar application of growth regulators and macro nutrients. Therefore, present experiment was planned to study the influence of foliar application of growth regulators and macro nutrients on seedling growth of Aonla. Current study helps 
to improve the seedlings growth and to develop graftable seedlings in short duration.

\section{Materials and Methods}

The present study was conducted at the Regional Horticultural Research and Extension Centre, University of Horticultural Sciences campus, Vidyaranyapura, Bangalore. The aonla seeds were collected from Aranya Bhavan, Malleswaram, Bengaluru, during the month of November 2011. Seedlings were raised in polythene bags containing regular potting mixture. Thirty six seeds were sown per treatment at $1-2 \mathrm{~cm}$ below the soil surface. There were thirteen treatments which were replicated thrice.

The treatments Viz., $\mathrm{T}_{1}: \mathrm{GA}_{3}$ 100ppm, $\mathrm{T}_{2}: \mathrm{GA}_{3}$ 200ppm, $\mathrm{T}_{3}: \mathrm{GA}_{3} 300 \mathrm{ppm}, \mathrm{T}_{4}$ : NAA 100ppm, $\mathrm{T}_{5}$ : NAA 200ppm, $\mathrm{T}_{6}$ : NAA 300ppm, $\mathrm{T}_{7}$ : Benzyl adenine 50ppm, $\mathrm{T}_{8}$ : Benzyl adenine $75 \mathrm{ppm}, \mathrm{T}_{9}$ : Urea $1 \%, \mathrm{~T}_{10}$ : Urea $2 \%, \mathrm{~T}_{11}$ : Water soluble NPK 1\%, $\mathrm{T}_{12}$ : Water soluble NPK 2\%, $\mathrm{T}_{13}$ : Control were sprayed for seedlings at 45 days after sowing.

The observations were recorded for plant height $(\mathrm{cm})$, stem diameter $(\mathrm{cm})$, number of leaves, fresh weight $(\mathrm{g})$, dry weight $(\mathrm{g})$ and days taken for attaining graftable size from 15 plants which were labeled. The experimental data collected relating to different parameters were statistically analyzed by Completely Randomized Design (CRD) and results were analyzed as per the guidelines suggested by Panse and Sukhatme (1967).

\section{Results and Discussion}

The influence of growth regulators and macronutrients on growth parameters of aonla seedlings is presented in table 1 . The maximum height $(37.00 \mathrm{~cm})$ was recorded in treatment $\mathrm{GA}_{3} 300$ ppm concentration which, was on par with $\mathrm{GA}_{3} 200 \mathrm{ppm}(35.33 \mathrm{~cm})$ at
120 days after spraying and minimum height was recorded in control $(27.00 \mathrm{~cm})$. Similar results were obtained in seedling stem diameter where maximum was in $\mathrm{GA}_{3} 300$ ppm $(0.61 \mathrm{~cm})$ which, was on par with $\mathrm{GA}_{3}$ $200 \mathrm{ppm}(0.59 \mathrm{~cm})$ and minimum was in control $(0.37 \mathrm{~cm})$. An increase in the plant height due to the growth regulators could be attributed to an increase in the meristematic activity of apical tissues. Growth regulators are involved in increasing photosynthetic activity, efficient translocation and utilization of photosynthates causing rapid cell elongation and cell division at growing region of the plant leading to stimulation of growth, besides increasing the uptake of nutrients (Dicks, 1980).

The gibberlic acid increases the plant height and seedling diameter in aonla mainly due to cell elongation, increase in cell size and rapid cell division.

Due to this the elongation of internodes will takes place, hence the seedling height will increase. Similar results were observed by Marler and Mickelbert (1992) in carambola, Kawthalkar and Kunte (1974) in rangpur lime, Hazart et al., (2006) in Araucaria heterophylla and Muralidhara et al., (2014) in mango.

The maximum number of leaves (42.33) was noticed in treatment $\mathrm{GA}_{3} 300 \mathrm{ppm}$. The production of more number of leaves in gibberlic acid treatments may be due to the vigorous growth with more number of branches and leaves which in turn facilitates better harvest of sunshine by the plants to produce more photosynthates.

These results obtained on this aspect are in agreement with Marler and Mickelbert (1992) in carambola, Kawthalkar and Kunte (1974) in rangpur lime, Hazart et al., (2006) in Araucaria heterophylla and Muralidhara et al., (2014) in mango. 
Table.1 Influence of growth regulators and macronutrients on seedling growth of aonla

\begin{tabular}{|l|c|c|c|c|c|c|}
\hline Treatments & $\begin{array}{c}\text { Seedling } \\
\text { height } \\
(\mathbf{c m})\end{array}$ & $\begin{array}{c}\text { Stem } \\
\text { diameter } \\
(\mathbf{c m})\end{array}$ & $\begin{array}{c}\text { Number } \\
\text { of leaves } \\
(\mathbf{c m})\end{array}$ & $\begin{array}{c}\text { Fresh } \\
\text { weight }(\mathbf{g})\end{array}$ & $\begin{array}{c}\text { Dry } \\
\text { weight } \\
(\mathbf{g})\end{array}$ & $\begin{array}{c}\text { Days taken for } \\
\text { graftable size }\end{array}$ \\
\hline T1 & 32.33 & 0.44 & 31.33 & 34.37 & 2.7 & 145.2 \\
\hline T2 & 35.33 & 0.59 & 38.67 & 39.6 & 3.07 & 137.4 \\
\hline T3 & 37 & 0.61 & 42.33 & 41.83 & 3.16 & 135.7 \\
\hline T4 & 31 & 0.4 & 32.67 & 27.53 & 2.12 & 162.2 \\
\hline T5 & 31 & 0.39 & 30.33 & 26.63 & 2.13 & 167.53 \\
\hline T6 & 33 & 0.41 & 29.33 & 29.1 & 2.33 & 158.8 \\
\hline T7 & 32.33 & 0.46 & 30.67 & 30.73 & 2.41 & 156.27 \\
\hline T8 & 35 & 0.46 & 37 & 33.83 & 2.7 & 150.93 \\
\hline T9 & 32.67 & 0.42 & 29 & 30.43 & 2.21 & 170.03 \\
\hline T10 & 32 & 0.39 & 34 & 26.8 & 2.18 & 169.07 \\
\hline T11 & 31.67 & 0.43 & 36 & 28.63 & 2.13 & 163.67 \\
\hline T12 & 33.33 & 0.41 & 35 & 28.3 & 2.22 & 160.47 \\
\hline T13 & 27 & 0.37 & 24.67 & 23.57 & 1.88 & 186.07 \\
\hline F test & $*$ & $*$ & $*$ & $*$ & $*$ & $*$ \\
\hline SEm \pm & 0.65 & 0.01 & 1.36 & 1.14 & 0.13 & 0.93 \\
\hline CD at 5\% & 1.95 & 0.03 & 4.08 & 3.42 & 0.39 & 2.79 \\
\hline
\end{tabular}

Table.2 Correlation matrix for different plant growth parameters

\begin{tabular}{|l|c|c|c|c|c|c|}
\hline Seedling height & $\begin{array}{c}\text { Seedling } \\
\text { height }\end{array}$ & $\begin{array}{c}\text { Seedling } \\
\text { girth }\end{array}$ & $\begin{array}{c}\text { Number } \\
\text { of leaves }\end{array}$ & $\begin{array}{c}\text { Fresh } \\
\text { weight }\end{array}$ & $\begin{array}{c}\text { Dry } \\
\text { weight }\end{array}$ & $\begin{array}{c}\text { Days taken for } \\
\text { graftable size }\end{array}$ \\
\hline Seedling girth & 0.81 & 1.00 & & & & \\
\hline Number of leaves & 0.84 & 0.78 & 1.00 & & & \\
\hline Fresh weight & 0.87 & 0.95 & 0.76 & 1.00 & & \\
\hline Dry weight & 0.86 & 0.93 & 0.75 & 0.98 & 1.00 & \\
\hline $\begin{array}{l}\text { Days taken for } \\
\text { graftable size }\end{array}$ & -0.87 & -0.86 & -0.78 & -0.93 & -0.95 & 1.00 \\
\hline
\end{tabular}

The maximum fresh weight $(41.83 \mathrm{~g})$ and dry weight $\left(3.16 \mathrm{~g}\right.$ ) was noticed in $\mathrm{GA}_{3} 300 \mathrm{ppm}$. The application of $\mathrm{GA}_{3}$ resulted in increase in fresh and dry weight of seedlings mainly due to the effect of $\mathrm{GA}_{3}$ being translocated to the expanding internodes and beyond into apical region and young leaves. The increase in length is accompanied by increased dry weight and during expansion, there is direct relation between dry weight and volume of water on the internode. The crude cell wall fraction of the dry weight also increases greatly and there is a direct relation between internode volume and amount of wall. This was also explained by Monselise and Halevy (1962) in citrus and Muralidhara et al., (2014) in mango.

The minimum number of days taken to reach graftable size (135.70 days) was recorded in 
$\mathrm{GA}_{3} 300 \mathrm{ppm}$. The minimum number of days taken to reach graftable size may be due to the vigorous growth induced by the gibberlic acid. The promotion of growth either in terms of increase in plant height or the stem girth and leaf number has been thought to be by increasing plasticity of the cell wall followed by hydrolysis of starch to sugars which lowers the water potential of cell, resulting in the entry of water into the cell causing elongation.

These osmotic driven responses under the influence of gibberellins might have attributed for increase in photosynthetic activity, accelerated translocation and efficiency of utilizing photosynthetic products, thus resulting in increased cell elongation and rapid cell division in the growing portion (Sargent, 1965).

Correlation matrix was worked out for different characters like seedling height, seedling girth, number of leaves, fresh weight and dry weight to known the relationship between the characters. Significant positive correlation was found among the different growth parameters, the values are represented in table 2.

The highly positive relationship among all the traits was obtained except number of days taken to attain graftable stage, which was negatively correlated with all the traits. In conclusion, the seedlings sprayed with $\mathrm{GA}_{3}$ $300 \mathrm{ppm}$ at 45 days after sowing recorded the maximum seedling height, stem diameter, number of leaves, fresh weight and dry weight also taken minimum number of days to attain graftable seedling stage.

\section{References}

Hazrat, G., Abdul, M. K. and Noorul A., Accelerating the growth of Araucaria heterophylla seedlings through different gibberellic acid concentrations and nitrogen levels. J. Agril. Biol. Sci., 1(2): 25-29 (2006).

Kawthalkar, M. P. and Kunte, Y. N., Effect of certain nursery management practices on growth of rangpur lime (Citrus limonia osbeek) seedlings. South Indian Hort., 22(3/4): 106-111 (1974).

Marler, T. E. and Mickelbart, M. V., Application of gibberlic acid to stem enhances the carambola seedling growth. Hort. Sci., 27(2): 122-123 (1992).

Monselise, S. P. and Halevy, A. H., Effects of gibberellin and AMO-1618 on growth, dry-matter accumulation, chlorophyll content and peroxidase activity of citrus seedlings. Amer. J. Bot., 49(4): 405-412 (1962).

Morton, J. F., The Emblica (Phyllanthus emblica L.). Economic Botany, 14: 119127 (1990).

Muralidhara, B. M., Reddy, Y. T. N., Shivaprasad, M. K., Akshitha, H. J. and Kishor, K. M., Studies on foliar application of growth regulators and chemicals on seedling growth of mango varieties. The Bioscan, 9(1): 203-205 (2014).

Panse, V. G. and Sukhatme, P. V., Statistical methods for agricultural worker. ICAR Publication, New Delhi, p330 (1967).

Sargent, J.A., The penetration of growth regulators into leaves. Ann. Rev. Pl. Physiol., 16: 1-12 (1965).

\section{How to cite this article:}

Chiranjeevi, M.R., M.K. Sneha, Shivanand Hongal and Muralidhara, B.M. 2018. Studies on Foliar Application of Growth Regulators and Macro Nutrients on Seedling Growth of Aonla. Int.J.Curr.Microbiol.App.Sci. 7(02): 3507-3510. doi: https://doi.org/10.20546/ijcmas.2018.702.417 